\title{
Reconsideration of Heteranthocidium (Oncidiinae, Orchidaceae): new species and taxonomic transfers
}

\author{
Dariusz L. Szlachetko • Marta Kolanowska
}

Received: 30 April 2014/Accepted: 19 December 2014/Published online: 18 January 2015

(C) The Author(s) 2015. This article is published with open access at Springerlink.com

\begin{abstract}
A new insight into the orchid genus Heteranthocidium is presented. The specific composition of the taxon is clarified. Eighteen new combinations within Heteranthocidium are proposed. Four of the species initially included in the genus, i.e. Oncidium boothianum, $O$. exalatum, $O$. fuscans and $O$. pollardii, should be no longer included in Heteranthocidium as they do not correspond to the morphological concept of the genus. The results of the conducted studies are compared with the molecular data on Oncidiinae. Seven new Heteranthocidium species are described and illustrated.
\end{abstract}

Keywords Neotropics - New combinations ·

Oncidium section Heterantha · Taxonomy

\section{Introduction}

The infrageneric classification of the genus Oncidium Sw. (Orchidaceae) is discussed for over 150 years when first two sections were delimited within the genus by Lindley (1842). Numerous sections within Oncidium were recognized by the subsequent researchers (e.g. Lindley and Paxton 1850; Kraenzlin 1922; Garay and Stacy 1974). Various previously described taxa were included in the genus, e.g. Basilata Lindl., Caucaea Schltr., Cohniella Pfitz., Cyrtochilum Kunth and Waluewa Regel. However,

Handling editor: Louis P. Ronse De Craene.

D. L. Szlachetko · M. Kolanowska ( $\square)$

Department of Plant Taxonomy and Nature Conservation,

University of Gdańsk, ul. Wita Stwosza 59, 80-308 Gdańsk,

Poland

e-mail: martakolanowska@wp.pl some of them were later restituted as separated genera. Recent morphologically based study revealed that some of the proposed infrageneric Oncidium taxa merit generic rank (Christenson 2006; Docha-Neto et al. 2006; Romowicz and Szlachetko 2006), e.g. Alatiglossum Baptista (sect. Barbata), Grandiphyllum Docha Neto. (sect. Pulvinata), Brasilidium Campacci (sect. Crispa), Brevilongium Christenson (sect. Serpentia) and Vitekorchis Romowicz \& Szlach. (sect. Excavata).

While the general flower structure are similar in most Oncidiinae, representatives of just one Oncidium section are characterized by dimorphic flowers. They were first included by Lindley into section Plurituberculata-hymenoptera-heterantha (Lindley 1855) and later into section Heterantha by Kraenzlin (1922). Recently, this taxon was elevated to the generic rank by Szlachetko et al. (2006) under the name Heteranthocidium. The authors recognized 15 species within newly established genus, and one species, Oncidium adelaidae Königer, was transferred here few years later (Kolanowska et al. 2011). The molecular studies of Neubig et al. (2012) revealed that Heteranthocidium sensu Szlachetko et al. (2006) is not monophyletic group. The authors proposed to combine it together with some other previously accepted genera (i.a. Odontoglossum Kunth, Sigmatostalix Rchb.f., Cochlioda Lindl., Symphyglossum Schltr., Miltonioides Brieger \& Lückel and Solenidiopsis Senghas) in Oncidium sensu latissimo. Unfortunately, in the broad concept, the genus is ill-defined at the morphological level. Based on the differences in the gynostemium structure, Szlachetko and Mytnik-Ejsmont (2009) recognized some of the taxa lumped in Oncidium as members of different subtribeSolenidiopsis and Cochlioda were included by those authors in Trichopiliinae together with i.a. Oliveriana and Cischweinfia. 


\section{Materials and methods}

A total of over 1,300 herbarium specimens and liquid preserved flowers of oncidioid orchids deposited in AMES, AMO, BM, COL, CUVC, F, FLAS, HUA, JAUM, K, MO, $\mathrm{NY}, \mathrm{P}, \mathrm{PMA}$, UGDA, VALLE and $\mathrm{W}$ were examined according to the standard procedures. Every studied sheet was photographed and the data from the labels were taken. Both vegetative and generative characters of each plant were examined. The shape and size of the pseudobulbs and leaves were studied first. Then the construction of the inflorescence and the shape and size of the floral bracts were examined. The morphology of flower was studied after its boiling using a stereomicroscope. At the end, the measurements were taken and the surface of each floral element was examined.

Acronyms for herbaria followed Index Herbariorum (Thiers 2014). The CorelDraw v.12 software was used to prepare distribution maps.

\section{Results}

The studies revealed that the previous treatment of Heteranthocidium, as synonymic with Kraenzlin's section Heterantha, needs reconsideration and its specific composition should be defined more precisely. Kraenzlin in his section Heterantha included 28 species, however, some of them were later recognized as synonyms (e.g. O. cuencanum Rchb.f. $=O$. cultratum Lindl., $O$. asparagoides Kraenzl. and $O$. zonatum Cogn. $=O$. bryolophotum Rchb.f., $O$. cheiri Rchb.f. ex Kraenzl and $O$. cycnicolle Rchb.f. $=O$. leopardinum Lindl.). Four of the species initially incorporated in Heteranthocidium, i.e. Oncidium boothianum Rchb.f., O. exalatum Hágsater, O. fuscans Rchb.f. and $O$. pollardii Dodson \& Hágsater, do not correspond to the morphological concept of the genus as they do not produce heteranthous inflorescence what was already stated by Neubig et al. (2012). While $O$. exalatum is a representative of Oncidium s.s., Oncidium boothianum and $O$. pollardi should be included in Vitekorchis Romowicz \& Szlach. and $O$. fuscans was transferred to Coppensia Dummort. by Campacci (2006).

The revised concept of Heteranthocidium is in accordance with the results of the molecular studies (Neubig et al. 2012). The clade Heteranthocidium is sister of the rest of Oncidium s.l. in the Neubig's phylogenetic tree (Fig. 1).

As currently recognized, the geographical range of the genus extends from Costa Rica to Bolivia and Brazil. Representatives of Heteranthocidium are usually found growing epiphytically in premontane and montane areas,

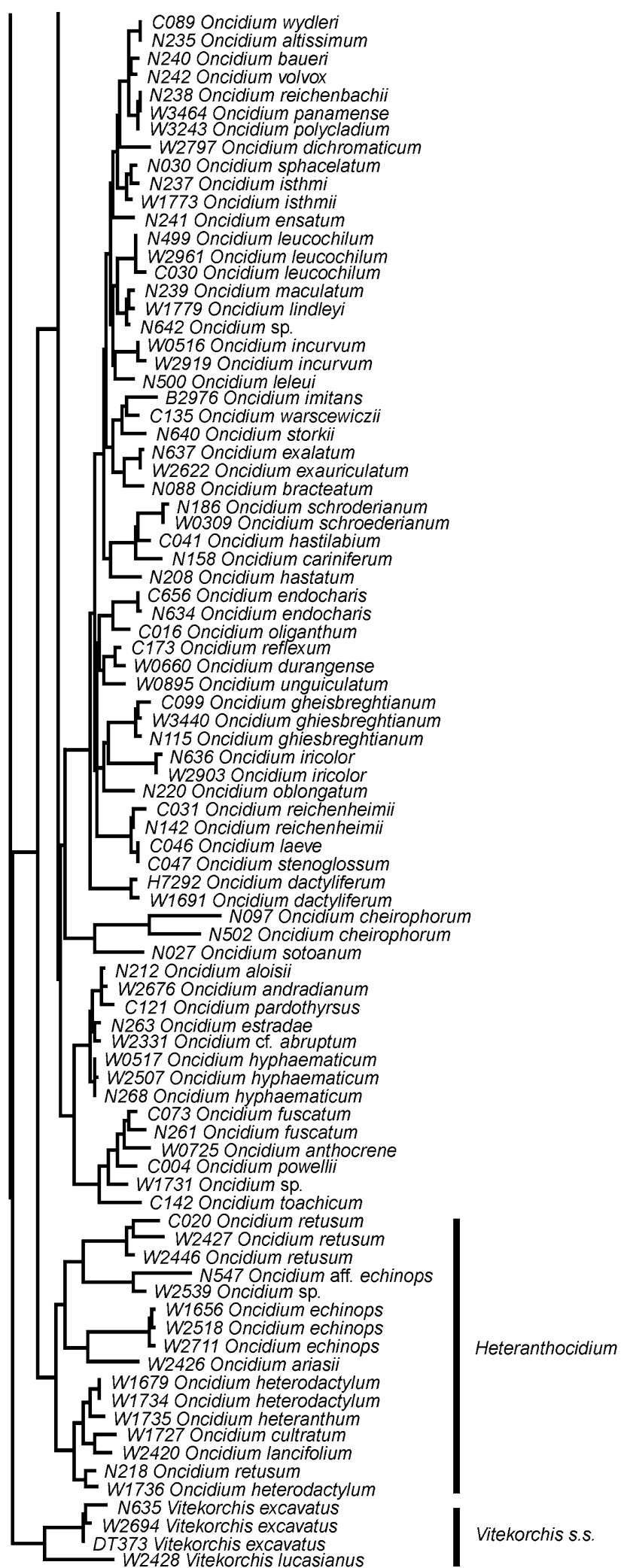

Fig. 1 Fragment of single maximum likelihood tree resulting from analysis of the combined seven-region dataset for 122 taxa presented by Neubig et al. (2012) 

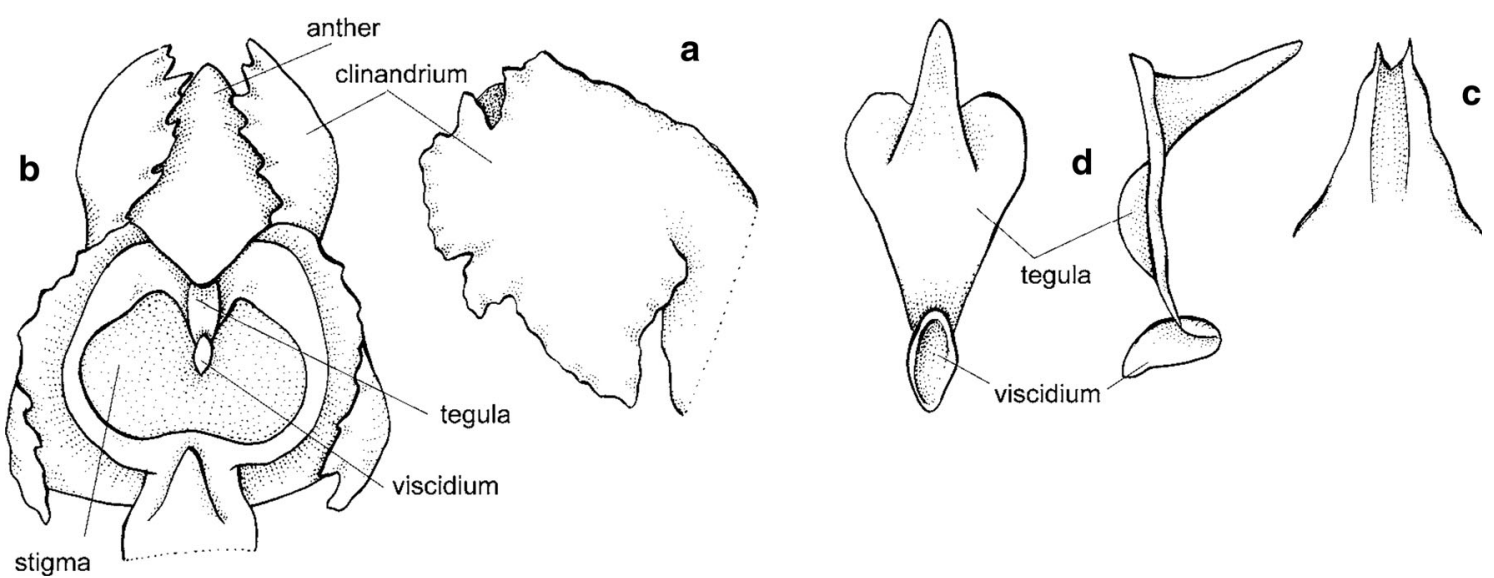

Fig. 2 Heteranthocidium heteranthum (Poepp. \& Endl.) Szlach., Mytnik \& Romowicz. a Gynostemium, side view, b Gynostemium, bottom view, c Rostellum remnant, front view, $\mathbf{d}$ Tegula and viscidium, various views (Chase 86016, UGDA-DLSz)

however, $H$. pentadactylon was found in higher elevations of about $3500 \mathrm{~m}$ (Senghas 1997).

During examination of the herbarium materials deposited in the Herbarium of National University in Bogota (COL) and Missouri Botanical Garden (MO), we found specimens which do not fit descriptions of any known species. Based on the most discriminative characters used in taxonomy of oncidioid orchids, i.a. type of the lip calli, lip form and gynostemium appendages (cf. Senghas 1997; Dalström 2010; Kolanowska and Szlachetko 2014), in our opinion, they merit the status of separate species.

\section{Taxonomic treatment}

\section{Heteranthocidium Szlach., Mytnik \& Romowicz}

Polish Bot. J. 51: 54. 2006.—TYPE: Heteranthocidium heteranthum (Poepp. \& Endl.) Szlach., Mytnik \& Romowicz

Epiphytic plants. Roots filiform. Pseudobulbs ellipsoid to ovoid, flattened, uni- or bi-foliate, partially enclosed at the base by longitudinally folded sheaths on each side. Leaf linear to obovate, thin. Inflorescence lateral, paniculate, many-flowered. Flowers resupinate, dimorphic, fertile flowers larger than the sterile ones, sterile flowers always stellate. Floral bracts shorter than the pedicels. Ovary glabrous. Tepals free, subsimilar, spreading, rarely bent back. Lip sessile or shortly clawed, entire to 3-lobed, with a prominent callus. Gynostemium short, rather massive, distinctly swollen above delicate and narrow base. Column part as long as anther or slightly longer, broadly winged near the stigma, wings obliquely subquadrate to obovate, sometimes bipartite, irregularly denticulate and/or papillate on margins. Anther ventral, incumbent, operculate, oblongovoid, dorsiventrally flattened, papillate. Connective narrow, slightly thickened on the dorsal surface. Pollinia 2, subglobose, dorsiventrally flattened, hard, unequally cleft, empty inside. Caudiculae sticky, amorphous. Apical clinandrium narrow. Stigma rather large, elliptic to transversely elliptic, deeply concave. Rostellum elongate, conical-digitate in the middle, obtuse. Viscidium single, very small, oblong to elliptic, thick, fleshy. Tegula single, oblong-obovate to oblong-triangular, thin, lamellate, elongate at the apex and here slightly thickened. Rostellum remnant bilobulate at the middle (Fig. 2).

\section{New species}

Heteranthocidium colombianum Szlach. \& Kolan., sp. nov.-HOLOTYPE: Colombia, Meta, Mpio. Mesetas, Vereda Villa Lucia, resguardo de Villa Lucia, comunidad indigena Paez, proveniente Cauca, approx. 30 anos. Microcuenca de la quebrada La Cristallina, 1,100 $\mathrm{m}$ a.s.l., $3^{\circ} 28^{\prime} 8.5^{\prime \prime}-24.2^{\prime \prime} \mathrm{N} 74^{\circ} 08^{\prime} 53.9^{\prime \prime}-09^{\prime} 00.9^{\prime \prime} \mathrm{W}, 8$ Oct $2002, R$. Lopez, J. Ramirez \& H. Yandi Campo 7570 (COL!) (Fig. 3).

Etymology: In reference to the country of origin of new species.

Pseudobulbs up to $6 \mathrm{~cm}$ tall and $1 \mathrm{~cm}$ in diameter, oblongoid, compressed, 2-leaved. Leaf shortly petiolate; petiole ca $1.5 \mathrm{~cm}$ long; blade up to $16 \mathrm{~cm}$ long and $1.4 \mathrm{~cm}$ wide, linear-lanceolate, acute. Inflorescence $80 \mathrm{~cm}$ long, laxly many-flowered, heavily branching, branches up to $6 \mathrm{~cm}$ long, usually with 1-3, terminal, fertile flowers and several sterile flowers below. Sterile flowers stellate, segments ca $4 \mathrm{~mm}$ long, linear. Fertile flowers-floral bracts $1.5 \mathrm{~mm}$ long, obscure, triangularovate, acute. Pedicellate ovary $11 \mathrm{~mm}$ long, slender. Dorsal sepal $7.5 \mathrm{~mm}$ long, $2.1 \mathrm{~mm}$ wide, basally shortly clawed, oblong-ligulate above, truncate at the apex, shortly acuminate. Petals $8 \mathrm{~mm}$ long, $3 \mathrm{~mm}$ wide, 


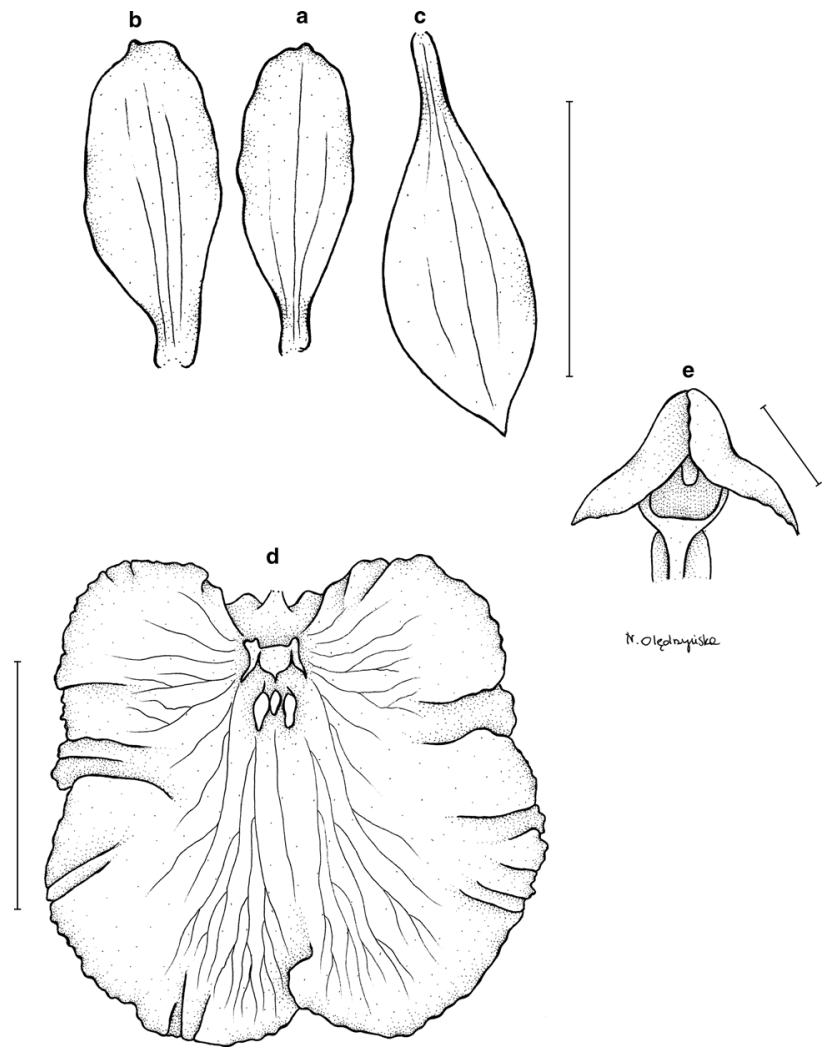

Fig. 3 Heteranthocidium colombianum a dorsal sepal, b petal, c lateral sepal, d lip. Scale bars $6 \mathrm{~mm}$. e Gynostemium. Scale bar $2 \mathrm{~mm}$. Drawn by N. Olędrzyńska from the holotype

basally shortly clawed, obliquely elliptic-ovate, apically truncate. Lateral sepals $9 \mathrm{~mm}$ long, $2.5 \mathrm{~mm}$ wide, oblong-elliptic above linear claw, oblique, acute. Lip $12 \mathrm{~mm}$ long and wide, shortly clawed, somewhat auriculate, subrectangular in outline, deeply notched at the apex, both apical lobes overlapping, margins irregularly crenulate, basal callus relatively small, thick, 3-lobed, with 3 additional knob-like calli below. Gynostemium $4 \mathrm{~mm}$ long, glabrous, staminodes touching each other in front of the anther.

Species similar in its habit to H. heteranthum (Poepp. \& Endl.) Szlach., distinguished by the unlobed lip, which is subquadrate in outline and narrow, ligulate petals and gynostemium wings touching each other in front of the anther.

Phenology: Flowering occurs in October.

Habitats: It grows at the altitude of about 760-1,100 m.

Distribution area: It occurs in Orinoco basin. The known localities are situated in Colombian Department of Meta. Alt. 760-1,100 m (Fig. 4).

Additional specimens examined: Colombia, Meta, Mpio. Mesetas, Trayecto Vereda Aguas Claras (escuela), Puente colgante del Rio Ariari, en cercanias a E, margen occidental del lado de la cordillera, 760-800 m a.s.l., 25 Oct 1995, J.L. Fernandez \& Estud. Sist. Veg. 12916 (COL!).

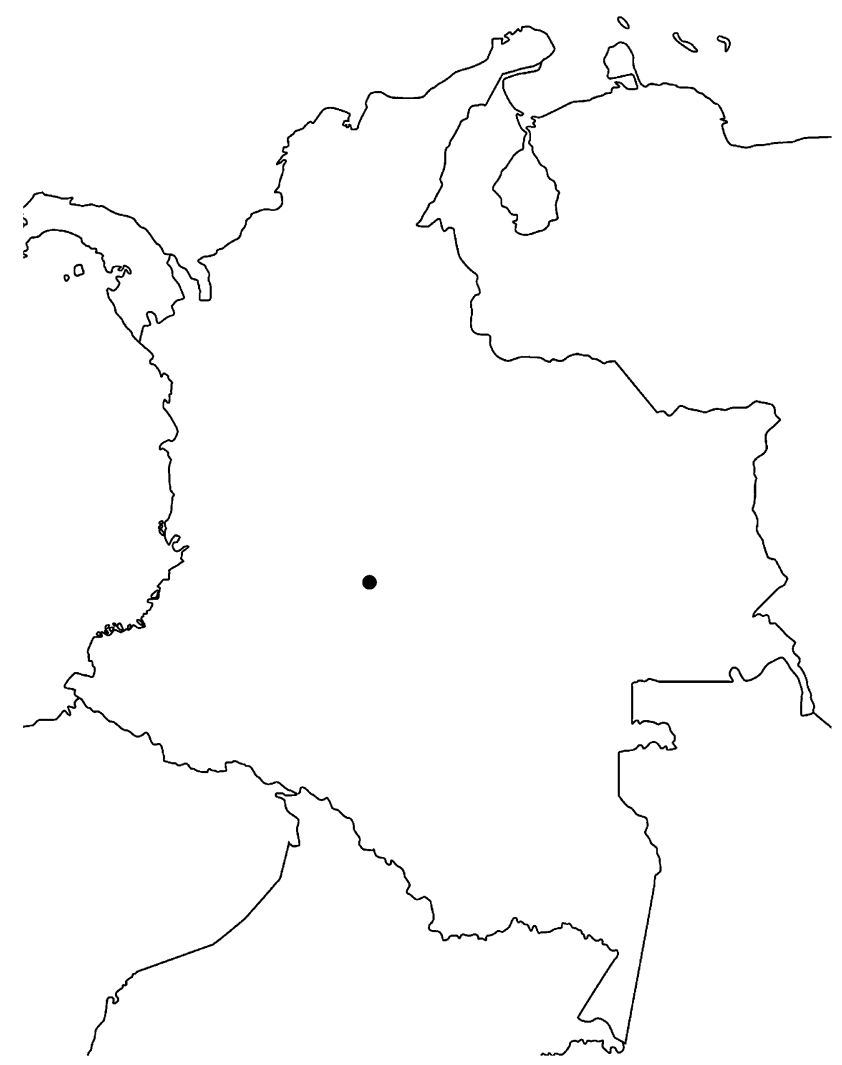

Fig. 4 Distribution of Heteranthocidium colombianum (spot) in Colombia

Notes: This species is unique in the genus by the shortly clawed, unlobed lip which is subquadrate in outline. The lip of other representatives of the genus is more or less 3-lobed.

Heteranthocidium garcia-barrigae Szlach. \& Kolan., sp. nov.-HOLOTYPE: Colombia, Cundinamarca, Sasaima, Vereda de Apocentos (Antigua hacienda de Apocentos), 10-12 Jul 1960, H. Garcia Barriga 17251 (COL!) (Fig. 5).

Etymology: Dedicated to the collector of the type specimen.

Pseudobulbs up to $5 \mathrm{~cm}$ tall and $1.5 \mathrm{~cm}$ in diameter, oblongoid, compressed, 1-leaved, concealed basally by large, leafy sheaths. Leaf shortly petiolate; petiole ca $1 \mathrm{~cm}$ long; blade up to $15 \mathrm{~cm}$ long and $3 \mathrm{~cm}$ wide, ligulatelanceolate, subacute. Inflorescence $70 \mathrm{~cm}$ long, laxly many-flowered, with some branches, which are secondarily branching, branches up to $5 \mathrm{~cm}$ long, usually with $1-2$, terminal, fertile flowers and several sterile flowers below. Sterile flowers stellate, segments ca $3 \mathrm{~mm}$ long, linear. Fertile flowers-floral bracts $2.7 \mathrm{~mm}$ long, triangularovate, acute. Pedicellate ovary $17 \mathrm{~mm}$ long, slender. Dorsal sepal $11 \mathrm{~mm}$ long, $3 \mathrm{~mm}$ wide, claw up to $5 \mathrm{~mm}$ long, linear, blade elliptic-obovate, rounded at the apex. Petals 

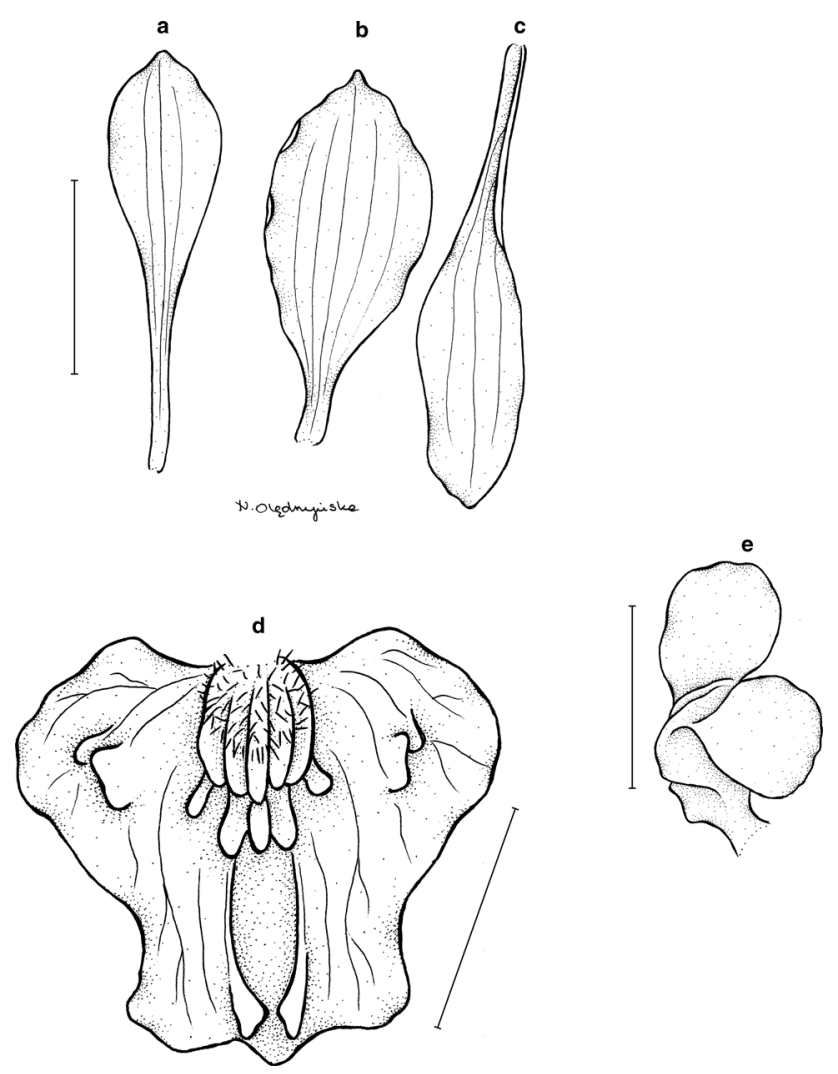

Fig. 5 Heteranthocidium garcia-barrigae a dorsal sepal, b petal, c lateral sepal, d lip, e gynostemium. Scale bars $5 \mathrm{~mm}$. Drawn by N. Olędrzyńska from the holotype

$11 \mathrm{~mm}$ long, $4.5 \mathrm{~mm}$ wide, basally shortly clawed, obliquely elliptic-obovate, apically acute, somewhat undulate. Lateral sepals $11 \mathrm{~mm}$ long, $2.5 \mathrm{~mm}$ wide, claw $5 \mathrm{~mm}$ long, linear, blade oblong-ligulate, subacute. Lip 8-9 mm long and wide, sessile, somewhat cordate at the base, lip middle lobe subrectangular or transversely elliptic, margins entire, basal callus relatively large, composed of 5 parallel ridges, ciliolate in the basal half, and 5 additional projections in front of them, 2 keels running from the apex of the callus to the lip apex forming a kind of channel. Gynostemium $8 \mathrm{~mm}$ long, glabrous, staminodes oblong-obovate.

Species similar to Heteranthocidium uribei Szlach. \& Kolan. from which it differs by the lip form, complex calli, ciliolate in the base with two keels running to the lip apex, and long-clawed sepals.

Phenology: Flowering throughout the year.

Habitats: This species is found usually in premontane forest. It grows epiphytically i.a. on Coffea arabica L. and Quercus humboldtii Bonpl., but is also found on fallen, dead branches in the forest with Bromus L. Its occurrence was reported up to altitude of about $2,140 \mathrm{~m}$.

Distribution area: Populations of this species occur along all three Andean Cordilleras in Colombia (Fig. 6).

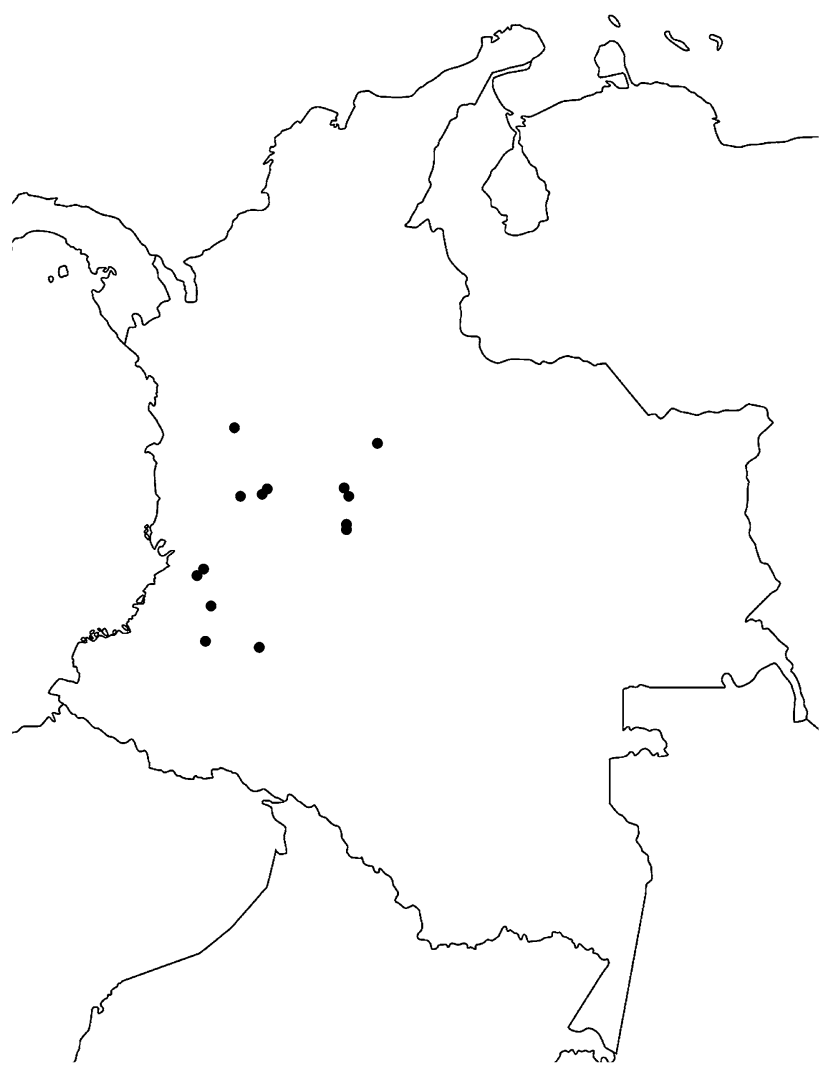

Fig. 6 Distribution of Heteranthocidium garcia-barrigae in Colombia

Additional specimens examined: Colombia, Boyacá, Mpio. Santa Marta. Vereda Cano Negro, finca Santa Rosa. Camino a Palonegro, $4^{\circ} 51^{\prime} 25.6^{\prime \prime}-39.3^{\prime \prime} \mathrm{N} 73^{\circ} 17^{\prime} 66.7^{\prime \prime}$ $20.8^{\prime \prime} \mathrm{W}, 1,550-1,800 \mathrm{~m}$ a.s.1., 3 Nov 2003, N. Salinas et al. 333 (COL!), Cauca, La Capilla, $25 \mathrm{~km} \mathrm{~N}$ of Popayan, 1,740 m a.s.l., 24 May 1944, E. Killip 38439 (COL!), Cauca, $5 \mathrm{~km}$ E of Timbio. Cordillera Central, 2,050 m a.s.l., 29 Dec 1944, M. Grant \& W. Drew 10672 (COL!), Popayán, Montes de Pisoje, 1,700 m a.s.l., 4 May 1949, A. Fernandez \& S. Yepes 56 (COL!); Chocó, La Mansa, 4 km via El Carmen, 1,900 m a.s.l., 20 Oct. 1980, G. Morales 227 (COL!), Cundinamarca, Mpio. San Bernardo, Cordillera Oriental, Vereda de Santa Rita, márgen izquierdo de la quebrada Unchia, 1,900 m a.s.1., 26 Jul 1981, R. Jaramillo, A. M. Cleef, O. Rangel \& S. Salamanca 7112 (COL!), Mpio. Tibacuy, A $1 \mathrm{~km}$ del Pueblo, 2 Apr 1989, A. Chaparro de Barrera \& E. Barrera de Torres $257 \& 268$ (COL!), Alban, 2,000 m a.s.l., 27 Jan 1949, M. Schneider 47 (COL!), En la carretera de Guayabetal a Manzanares, 1,600 m a.s.1., 5 Mar 1961, H. Schmidt-Mumm 38 (COL!), Risaralda, Mpio. Pereira, La Suiza. Camino a Callejones, 1,950 m a.s.l., 13 Jun 1989, P. Franco, G. Galeano, N. Ladino, A. Castillo \& F. Forero 2653 \& 2654 (COL!), Mpio. Santa Rosa de Cabal, Vereda La Colina, $4^{\circ} 56^{\prime} \mathrm{N}$ 
$75^{\circ} 42^{\prime} \mathrm{W}, 1,725 \mathrm{~m}$ a.s.1., 22 Oct 1985, J. Wolf 324 (COL!), Tolima, Sine loc., 12 Jan 2002, M. Ospina H. 1551 (COL!), Valle del Cauca, Mpio. Argelia, Vereda Las Brisas, finca San Jorge, 1,950 m a.s.1., 22 Jan 1983, P. Franco, O. Rangel, Cleef \& S. Salamanca 1715 (COL!), Vereda Las Brisas, 2,140 m a.s.l., 21 Jan 1983, P. Franco, O. Rangel, Cleef \& S. Salamanca 1668 (COL!), El Queremal, 20 Jan 1980, I. Guarin O. 53 (COL!), Bosque de Yotoco, 15 Jan 1980, I. Guarin O. 38 (COL!), The same loc., 4 Apr 1980, I. Guarin O. 132 (COL!), La Cumbre, $4 \mathrm{~km}$ via Yumbo, 1,770 m a.s.1., 22 Apr 1979, G. Morales, J. \& M. Luteyn 124 (COL!), Monte Frio, Yanaconas, 1,700-1,850 m a.s.1., 27 Feb-1 Mar 1939, E. Killip \& H. Garcia 33700 (COL!).

Notes: This species resembles $H$. uribei described in this paper from which it differs by the lip shape which is trullate-reniform in the latter orchid, callus being basally ciliolate in $H$. garcia-barrigae, presence of two keels on the lip disc running to the apex, and long-clawed sepals (vs. claw short in $H$. uribei). Unlike in $H$. acinaceum (Lindl.) Szlach., Mytnik \& Romowicz the lip middle lobe of $H$. garcia-barrigae is subrectangular or transversely elliptic in outline.

Heteranthocidium gaviotaense Szlach. \& Kolan., sp. nov.-HOLOTYPE: Colombia, Risaralda, Mpio. Santa Rosa de Cabal, Al W de Termales de Santa Rosa. Hacienda La Gaviota, 1,980 m a.s.1., $4^{\circ} 51^{\prime} \mathrm{N} 75^{\circ} 34^{\prime} \mathrm{W}, 27$ Nov 1985, J. Wolf 449 (COL!; isotype: MO!) (Fig. 7).

Etymology: In reference to the place of the origin of the type specimen.

Pseudobulbs up to $7 \mathrm{~cm}$ tall and $2 \mathrm{~cm}$ in diameter, oblongoid-ovoid, compressed, 2-leaved, concealed basally by large, leafy sheaths. Leaf shortly petiolate; petiole $1-3 \mathrm{~cm}$ long; blade up to $15 \mathrm{~cm}$ long and $2.2 \mathrm{~cm}$ wide, linearoblanceolate, subacute. Inflorescence up to $90 \mathrm{~cm}$ long, laxly many-flowered, with some branches, which are secondarily branching, branches up to $5 \mathrm{~cm}$ long, usually with $1-2$, terminal, fertile flowers and several sterile flowers below. Sterile flowers stellate, segments linear, ca $2-3 \mathrm{~mm}$ long. Fertile flowers-floral bracts $2 \mathrm{~mm}$ long, triangularovate, acute. Pedicellate ovary $17 \mathrm{~mm}$ long, slender. Dorsal sepal 9-9.5 mm long, $2.2 \mathrm{~mm}$ wide, claw linear, blade elliptic-ligulate, rounded at the apex. Petals $8-8.2 \mathrm{~mm}$ long, $3.2 \mathrm{~mm}$ wide, sessile, obliquely ligulate, apically obtuse. Lateral sepals $8.5 \mathrm{~mm}$ long, $2.2 \mathrm{~mm}$ wide, claw linear, blade oblong-ligulate, subobtuse, oblique. Lip $10 \mathrm{~mm}$ long and wide, sessile, somewhat cordate at the base, basal part suborbicular in outline, lip middle lobe bilobulate, sinus deep, lobules obliquely ligulate, margins entire, basal callus relatively large, composed of 3 rows of 3 parallel ridges, glabrous. Gynostemium $5 \mathrm{~mm}$ long, glabrous, staminodes bilobed, margins irregularly crenulate, apex rounded.

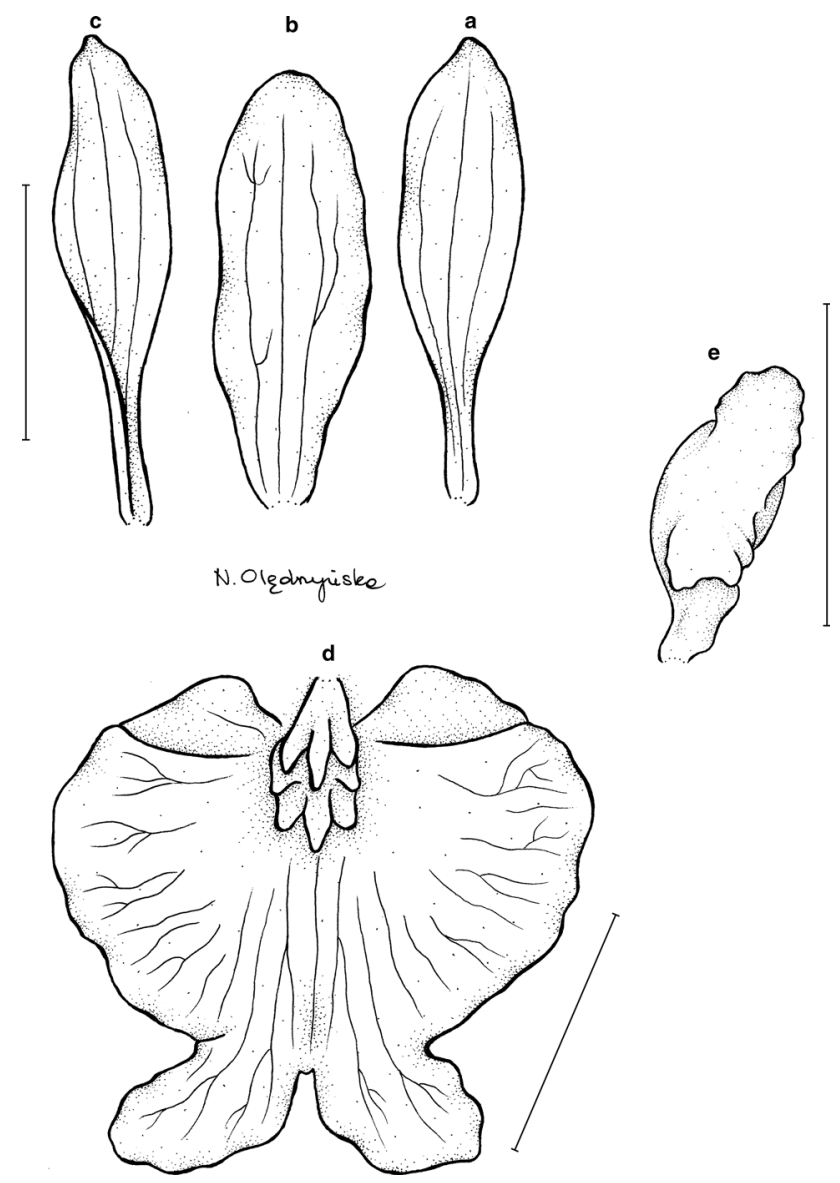

Fig. 7 Heteranthocidium gaviotaense a dorsal sepal, b petal, c lateral sepal, d lip, e gynostemium. Scale bars $5 \mathrm{~mm}$. Drawn by $\mathrm{N}$. Olędrzyńska from the holotype

Species similar to $H$. aspecum (Königer) Szlach. \& Kolan., but with semicircular lip lateral lobes, obliquely ovate lip middle lobe lobules, callus consisting of eight tooth-like protuberances and glabrous gynostemium.

Phenology: Flowering occurs in March and November.

Habitats: Epiphytic in subandean forest with Cecropia Loefl., Hieronyma alchorneoides Allemão and Miconia acuminifera Triana. It grows at the altitudes of about $1,500-1,980 \mathrm{~m}$.

Distribution area: Populations of this species were found in Western and Central Cordilleras of the Colombian Andes (Fig. 8).

Additional specimens examined: Colombia, Cundinamarca, Mpio. Tibacuy, A 1 km del Pueblo, 19 Mar 1992, A. Chaparro de Barrera \& E. Barrera Torres 257 (COL!).

Notes: Species similar to $H$. aspecum but with semicircular lip lateral lobes (vs. lobes ovate), obliquely ovate lip middle lobe lobules (vs. circular), callus consisting of eight tooth-like protuberances (vs. callus irregularly manydigitate, with 3 short, obliquely ascending lamellae) and glabrous gynostemium (vs. pubescent below stigma). 


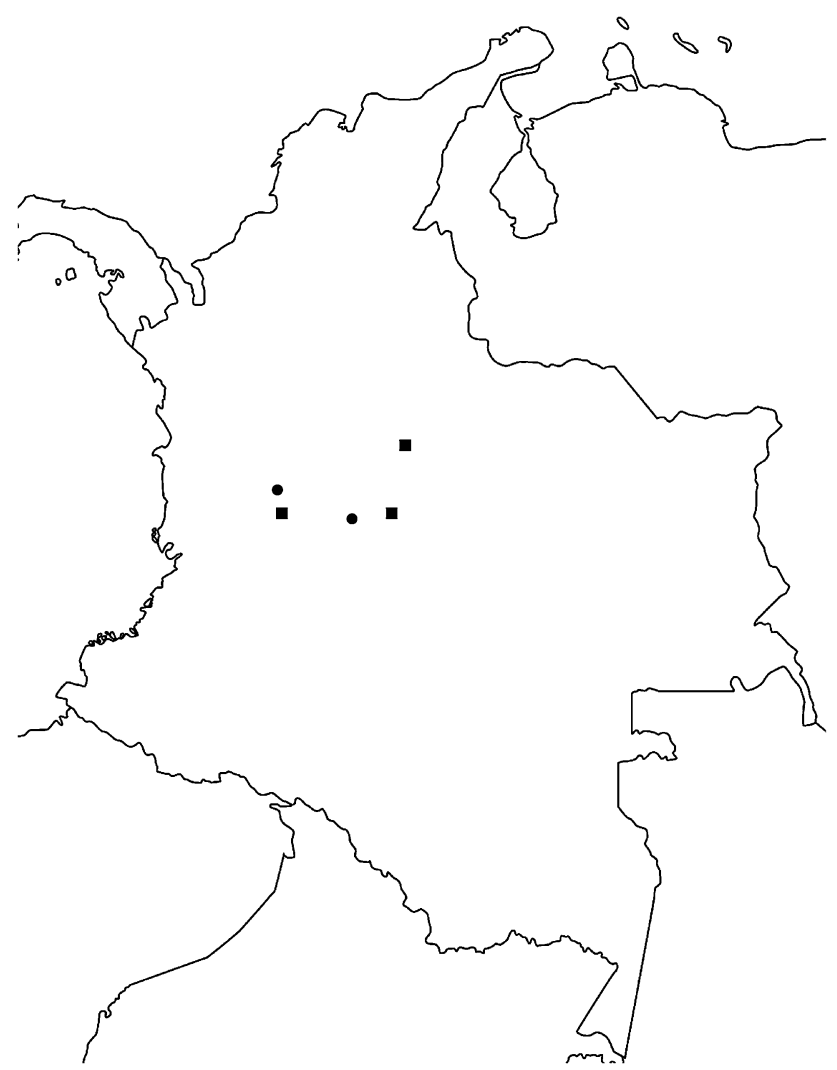

Fig. 8 Distribution of Heteranthocidium gaviotaense (spot) and $H$. subnivalis (square) in Colombia

Heteranthocidium aspecum together with $H$. millei is sometimes considered as synonymic with $H$. pentadactylon, however, the petals of last species are shortly unguiculate with ovate blade. In two former taxa, they are long-unguiculate (H. aspecum) or ligulate $(H$. millei). The variation of lip callus shape within these species requires further studies, however, we prefer to considered them as separated taxa until more data will be available. Heteranthocidium gaviotaense also resembles $H$. rostrans from which it differs by the lip lateral lobes shape and unlobed gynostemium wings.

Heteranthocidium sipaliwinense Szlach. \& Kolan., sp. nov.-HOLOTYPE: Suriname, Sipaliwini, Trail from Lisa Kreek to Grace falls, Tafleberg Mountain, Trail between the Lisa Kreek camp to the camp on the Grace Kreek, 600-700 m a.s.1., $3^{\circ} 54^{\prime} 32^{\prime \prime} \mathrm{N} 56^{\circ} 12^{\prime} 44^{\prime \prime} \mathrm{W}, 29$ Jun 1998, $T$. Hawkins 1849 (MO!) (Fig. 9).

Etymology: In reference to the place of origin of the type specimen.

Pseudobulbs up to $2 \mathrm{~cm}$ tall and $0.8 \mathrm{~cm}$ in diameter, oblongoid-ovoid, compressed, 1-leaved, concealed basally by leafy sheaths. Leaf shortly petiolate; petiole ca $0.5 \mathrm{~cm}$ long; blade up to $4 \mathrm{~cm}$ long and $0.7 \mathrm{~cm}$ wide, ligulatelanceolate, acute. Inflorescence $20 \mathrm{~cm}$ long, laxly few-
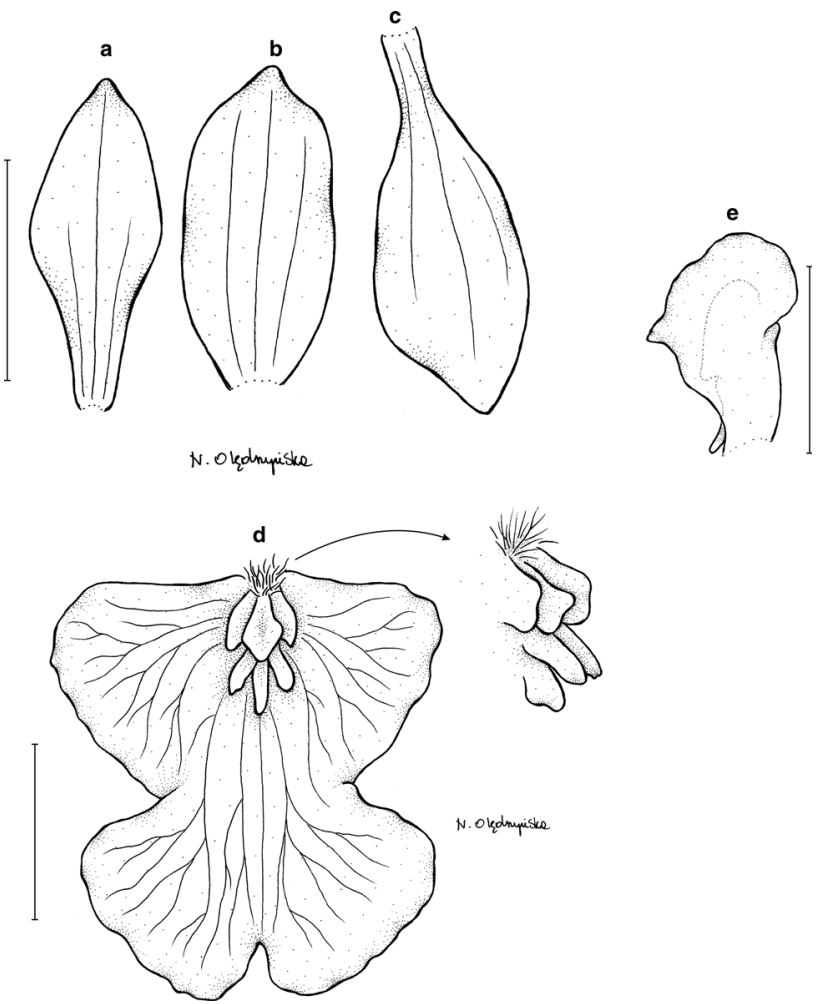

Fig. 9 Heteranthocidium sipaliwinense a dorsal sepal, b petal, c lateral sepal, d lip, e gynostemium. Scale bars $4 \mathrm{~mm}$. Drawn by N. Olędrzyńska from the holotype

flowered, with few, short branches. Sterile flowers stellate. Fertile flowers-floral bracts $1 \mathrm{~mm}$ long, obscure, triangular-ovate, acute. Pedicellate ovary $12 \mathrm{~mm}$ long, slender. Dorsal sepal $6 \mathrm{~mm}$ long, $2.5 \mathrm{~mm}$ wide, sessile, blade elliptic-ovate, subacute at the apex. Petals $6.5 \mathrm{~mm}$ long, $2.8 \mathrm{~mm}$ wide, sessile, obliquely elliptic, apically subacute. Lateral sepals $6.5 \mathrm{~mm}$ long, $2.2 \mathrm{~mm}$ wide, claw linear, blade oblong-obovate, subacute, oblique. Lip $10 \mathrm{~mm}$ long, $9.5 \mathrm{~mm}$ wide in the basal part and $9 \mathrm{~mm}$ wide across middle lobe, sessile, truncate at the base, basal part subtriangular in outline, lip middle lobe transversely rhombic in outline, bilobulate, sinus prominent, margins entire, basal callus relatively large, consists of 2 rows of 3 parallel ridges, pubescent at the base only. Gynostemium $4.7 \mathrm{~mm}$ long, glabrous, staminodes bilobed, rounded at the apex.

Species similar to H. heteranthum (Poepp. \& Endl.) Szlach., Mytnik \& Romowicz from which it differs by the basally pubescent lip callus that is composed of a subrhombic, laterally flattened pad surrounded by five digitate projections.

Phenology: Flowering occurs in June.

Habitats: Grows epiphytically in mixed forest at the altitude of about $600-740 \mathrm{~m}$. 


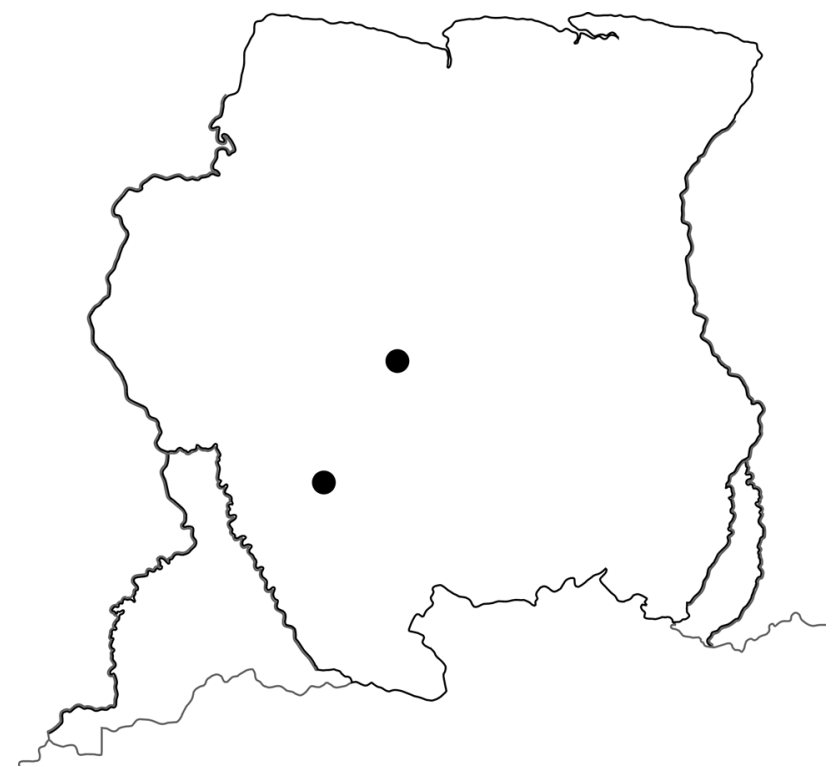

Fig. 10 Distribution of Heteranthocidium sipaliwinense in Suriname

Distribution area: This species is known exclusively from Suriname (Fig. 10).

Additional specimens examined: Suriname, Distr. Sipaliwini, Central Suriname Nature Reserve. On the upper slopes and summit the first peak in Eilerts de Haan mountain range ca $7 \mathrm{~km}$ ENE of Kayserberg Airstrip, $650-740$ m a.s.1., $3^{\circ} 09^{\prime} 50^{\prime \prime} \mathrm{N} 56^{\circ} 27^{\prime} 40^{\prime \prime} \mathrm{W}, 21$ Jun 2003, G.

Herrera \& S. Koemar 10017 (MO!).

Notes: This species resembles $H$. heteranthum from which it differs by the basally pubescent lip callus (vs. callus glabrous) that is composed of a subrhombic, laterally flattened pad surrounded by five digitate projections (vs. callus consisting of several irregular ridges).

Heteranthocidium subnivalis Szlach. \& Kolan., sp. nov.-HOLOTYPE: Colombia, Quindio, Mpio. Salento, Novarco. Bosque alrededor de la estación piscicola, 3,000 m a.s.l., Sep 1992, J. Betancur, L. Mendoza, L. Montero \& L. Rios 3624 (COL!) (Fig. 11).

Etymology: An allusion to the altitude where the plants occur.

Pseudobulbs up to $5 \mathrm{~cm}$ tall and $2 \mathrm{~cm}$ in diameter, oblongoid-ovoid, compressed, 2-leaved, concealed basally by large, leafy sheaths. Leaf shortly petiolate; petiole ca $1 \mathrm{~cm}$ long; blade up to $15 \mathrm{~cm}$ long and $2.2 \mathrm{~cm}$ wide, linearoblanceolate, subacute. Inflorescence $60-70 \mathrm{~cm}$ long, laxly many-flowered, with some branches, which are secondarily branching, branches up to $5 \mathrm{~cm}$ long, usually with $1-2$, terminal, fertile flowers and several sterile flowers below. Sterile flowers stellate, segments ca $3 \mathrm{~mm}$ long, linear. Fertile flowers-floral bracts $2 \mathrm{~mm}$ long, triangular-ovate, acute. Pedicellate ovary $14 \mathrm{~mm}$ long, slender. Dorsal sepal $10 \mathrm{~mm}$ long, $2.1 \mathrm{~mm}$ wide, claw linear, blade elliptic-

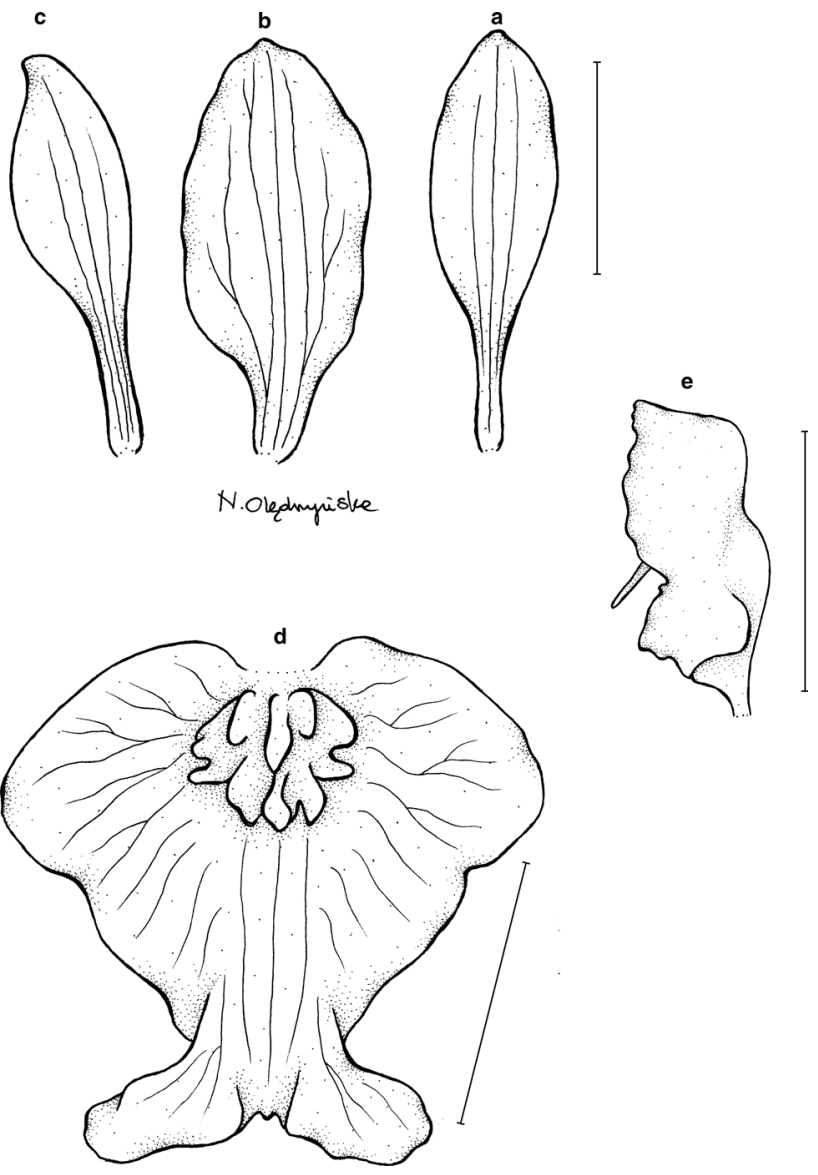

Fig. 11 Heteranthocidium subnivalis a dorsal sepal, b petal, c lateral sepal, d lip, e gynostemium. Scale bars $5 \mathrm{~mm}$. Drawn by $\mathrm{N}$. Olędrzyńska from the holotype

ligulate, rounded at the apex. Petals $9 \mathrm{~mm}$ long, $4 \mathrm{~mm}$ wide, basally shortly clawed, obliquely elliptic, apically obtuse. Lateral sepals $8-9 \mathrm{~mm}$ long, $2.8 \mathrm{~mm}$ wide, claw linear, blade oblong-ovate, subacute, oblique. Lip $10 \mathrm{~mm}$ long, $11 \mathrm{~mm}$ wide, sessile, somewhat cordate at the base, basal part subtriangular in outline, lip middle lobe lobules ligulate, margins entire, basal callus relatively large, composed of 5 parallel ridges, ciliolate at the base only. Gynostemium $6.2 \mathrm{~mm}$ long, glabrous, staminodes bilobed, margins irregularly crenulate.

Species similar to $H$. aspecum but with triangular lip lateral lobes, basally pubescent callus in form of toothed pad and glabrous gynostemium.

Phenology: Flowering occurs in March and between September and December.

Habitats: It was found growing in cloud forest dominated by Myrsinaceae, Melastomataceae, species of Palicourea Aubl., Drymis Juss. and Weinmannia L. It was found at the altitudes of 2,900-3,550 m.

Distribution area: Known only from Colombian Central and Western Cordilleras of the Andes (Fig. 8). 
Additional specimens examined: Colombia, Boyacá, Mpio. Villa de Leyva, Santuario de Flora y Fauna de Iguaque, camino entre la cabana carrizal y Laguna de Iguaque, 2,900-3,550 m a.s.l., 29 Mar 1993, J. Betancur, P. Franco \& Estud. Prof. 4123 (COL!), Cundinamarca, Fómeque. Paramo de Chingaza. La Laja y alrededores, 3,200 m a.s.l., 11-23 Dec 1966, G. Huertas \& L. Camargo 5704 (COL!), Fómeque. Paramo de Chingaza. Subseriales vecinos a La Laguna, 3,230 m a.s.l., 2 Nov 1967, G. Huertas \& L. Camargo 6569 (COL!).

Notes: This species is similar to H. aspecum, from which it differs by the lip lateral lobes shape (triangular vs. ovate), basally pubescent callus (vs. callus glabrous) in form of toothed pad (vs. callus irregularly many-digitate, with 3 short, obliquely ascending lamellae) and glabrous gynostemium (vs. gynostemium pubescent below the stigma). It also resembles H. lepturum (Rchb.f.) Szlach. \& Kolan., from which it differs in the lip middle lobe lobules shape (ligulate vs. ovate) and lack of protuberances on the lip lateral lobes.

Heteranthocidium uribei Szlach. \& Kolan., sp. nov.HOLOTYPE: Colombia, Cundinamarca, Mpio. Tena, Laguna de Pedro Palo, 2100 m a.s.l., 24 Jun 1948, L. Uribe Uribe 1745 (COL!) (Fig. 12).

Etymology: Dedicated to Lorenzo Uribe Uribe, collector of the type specimen.

Pseudobulbs up to $4 \mathrm{~cm}$ tall and $1 \mathrm{~cm}$ in diameter, ellipsoid, compressed, 1-leaved. Leaf shortly petiolate; petiole ca $1.5 \mathrm{~cm}$ long; blade up to $10.5 \mathrm{~cm}$ long and $3.2 \mathrm{~cm}$ wide, oblong-elliptic, rounded. Inflorescence $70 \mathrm{~cm}$ long, laxly many-flowered, heavily branching, branches up to $6 \mathrm{~cm}$ long, usually with $1-3$, terminal, fertile flowers and several sterile flowers below. Sterile flowers stellate, segments ca $5 \mathrm{~mm}$ long, linear. Fertile flowers-floral bracts $2.5 \mathrm{~mm}$ long, triangular-ovate, acute. Pedicellate ovary $12 \mathrm{~mm}$ long, slender. Dorsal sepal $10 \mathrm{~mm}$ long, $3 \mathrm{~mm}$ wide, basally clawed, elliptic-ligulate above, truncate at the apex. Petals $10 \mathrm{~mm}$ long, $5.5 \mathrm{~mm}$ wide, basally shortly clawed, obliquely elliptic, apically acute, somewhat undulate. Lateral sepals $11 \mathrm{~mm}$ long, $2.5 \mathrm{~mm}$ wide, claw $5 \mathrm{~mm}$ long, linear, blade oblong-elliptic, oblique, subobtuse. Lip $8 \mathrm{~mm}$ long, $11 \mathrm{~mm}$ wide, trullate-reniform in outline, sessile, somewhat cordate at the base, margins entire, basal callus relatively large, composed of several projections of various size and form, with 2 additional knob-like calli on each side. Gynostemium $7 \mathrm{~mm}$ long, glabrous, staminodes bilobed, the lower lobes triangular, acute, the upper lobes oblong-obovate, overlapping each other in front of the anther.

Species similar to H. abortivum (Rchb.f.) Szlach., Mytnik \& Romowicz, distinguished by trullate-reniform lip, reduced, entire lip middle lobe and large bilobed staminodes which upper lobes are overlapping.

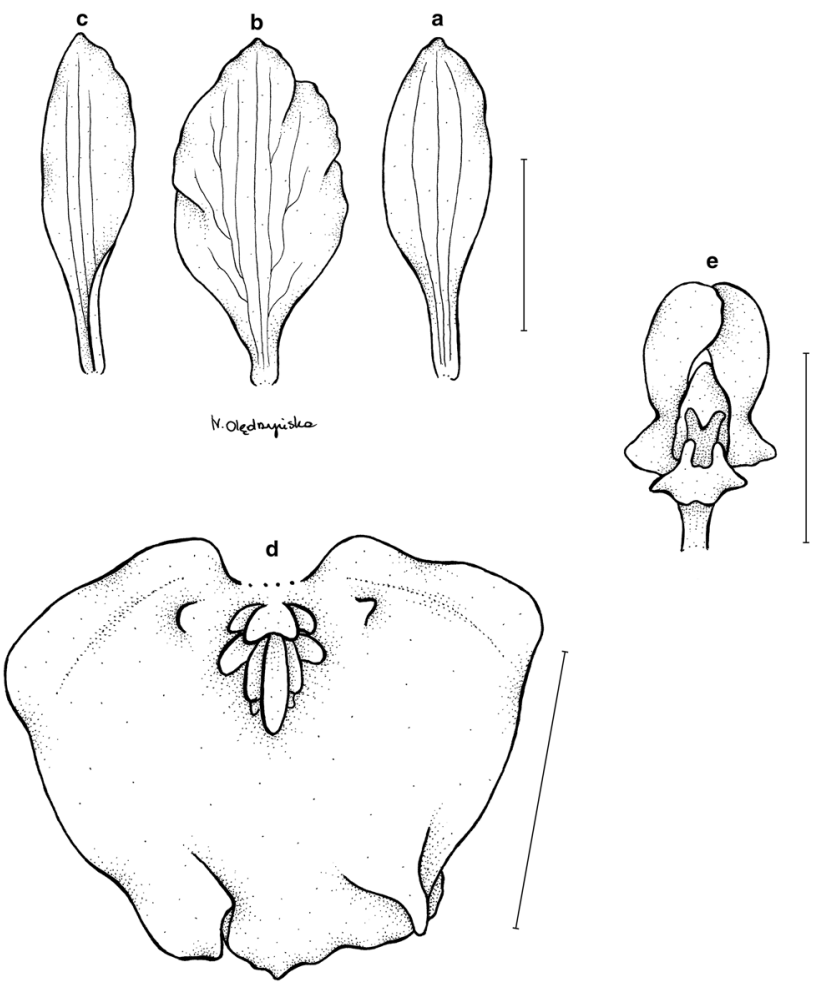

Fig. 12 Heteranthocidium uribei a dorsal sepal, b petal, c lateral sepal, d lip, e gynostemium. Scale bars $5 \mathrm{~mm}$. Drawn by $\mathrm{N}$. Olędrzyńska from the holotype

Phenology: Flowering throughout the year.

Habitats: This species grows epiphytically on the edges of premontane and montane forest, along the streams and small lakes. It was reported growing on Matisia uribei (García-Barr. \& Hern.Cam.) Cuatrec. It was found at the altitudes of 1,550-2,285 m.

Distribution area: Known exclusively from Colombia. Populations are distributed within Western and Central Andean Cordilleras with a single locality known from Cordillera de Perijá (Fig. 13).

Additional specimens examined: Colombia, Cundinamarca, Mpio. Tena, Tena, bosque a la orilla de la Laguna de Pedropalo, Alt. 2,050 m a.s.l., 24 Jan 1966, L. Uribe Uribe 5499 (COL!), Rocas de Sumapaz, La Cabrera, Jul 1930, EPA 604 (COL!), Supata-San Francisco Road, 1,900 m a.s.1., 31 Aug 1947, Haught 6127 (COL!), Magdalena, Sierra de Perija. E of Manaure. Hacienda Nuevo Horizonte, El Podrido, 1,550-1,600 m a.s.1., 15-16 Nov 1959, J. Cuatrecasas \& R. Romero Castaneda 25379 (COL!), Quindio, Mpio. Filandia, La Gironda, 1,700 m a.s.l., 26 Mar 1999, W. Vargas 5706 (COL!), Lusitiana, 1,800 m a.s.1., Jul 2002, W. Vargas 9827 (COL!), Quindio/ Risaralda, Mpio. Pereira, La Suiza. Rio Otun, 1,800-2,200 m a.s.1., Nov 2002, W. Vargas 10287 (COL!), Risaralda, Mpio. Apia, Vereda La Cumbre, 2,285 m a.s.l., 


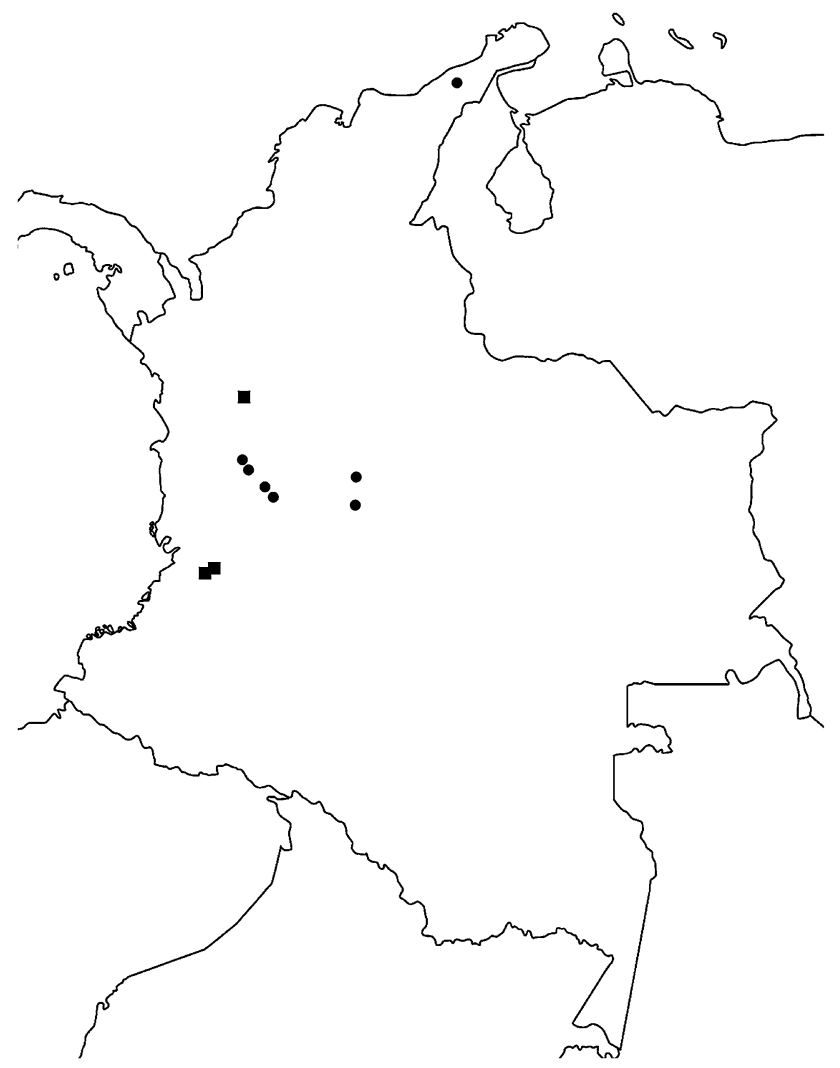

Fig. 13 Distribution of Heteranthocidium uribei (spot) and $H$. vallecaucanum (square) in Colombia

24 Feb 1983, J. Torres, O. Rangel, P. Franco, Cleef \& S. Salamanca 2221 (COL!), Mpio. Pueblo Rico, Vereda Tatama, Cuenca del Rio Tatama, Reserva Karagabi (Arbol de Agua en laguna Embera), $2,020 \mathrm{~m}$ a.s.l., $5^{\circ} 00^{\prime} \mathrm{N}$ $76^{\circ} 01^{\prime} 00^{\prime \prime} \mathrm{W}, 5$ Jan 2001, R. Lopez, N. Rodriguez \& D. Camacho 6940 (COL!), En bosque de Niebla, Reserva Karagabi, Microcuenca de la quebrada la Mansa, 2,200 m a.s.l., $5^{\circ} 00^{\prime} \mathrm{N} 76^{\circ} 01^{\prime} 00^{\prime \prime} \mathrm{W}, 6$ Jan 2001, R. Lopez, $N$. Rodriguez, D. Camacho \& Estud. 7018 (COL!).

Notes: Heteranthocidium uribei is distinguished by trullate-reniform lip, with complex calli and staminodes which are bilobed with upper lobes being oblong-obovate and overlapping each other. The lip of $H$. abortivum is 3-lobed, with rounded, auriculate to rhomboid lateral lobes and triangular, triangular-ovate to lanceolate middle lobe.

Heteranthocidium vallecaucanum Szlach. \& Kolan., sp. nov.-HOLOTYPE: Colombia, Valle del Cauca, Mpio. Yumbo, Finca La Samaria, NE of Darien, near Lago Calima (reservoir), 1,800-2,000 $\mathrm{m}$ a.s.1., $4^{\circ} 7^{\prime} \mathrm{N} 76^{\circ} 30^{\prime} \mathrm{W}, 15$ Feb 1984, A. Juncosa 2199 (MO!) (Fig. 14).

Etymology: In reference to the place of collection of the type specimen.

Pseudobulbs up to $5 \mathrm{~cm}$ tall and $1.1 \mathrm{~cm}$ in diameter, oblongoid-ovoid, compressed, 1-leaved, concealed basally
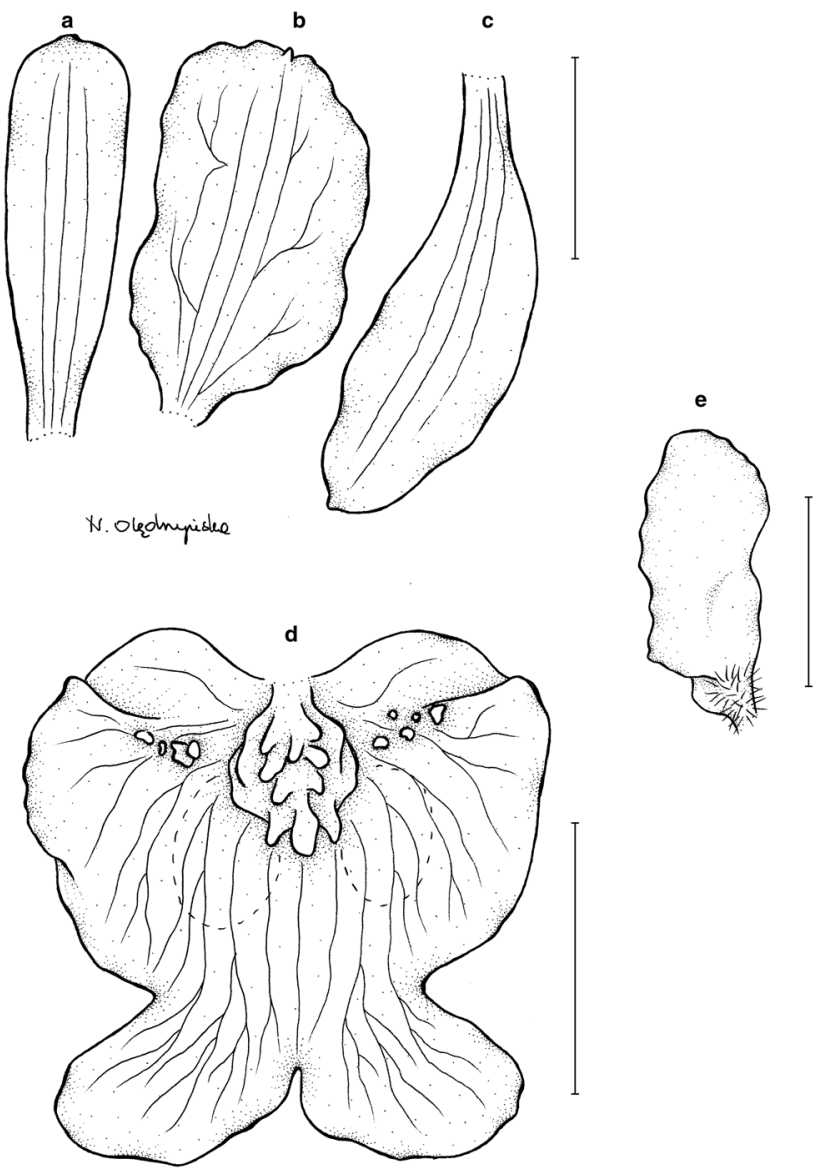

Fig. 14 Heteranthocidium vallecaucanum a dorsal sepal, b petal, c lateral sepal, d lip, e gynostemium. Scale bars $5 \mathrm{~mm}$. Drawn by N. Olędrzyńska from the holotype

by large, leafy sheaths. Leaf shortly petiolate; petiole ca $2 \mathrm{~cm}$ long; blade up to $9.5 \mathrm{~cm}$ long and $2.5 \mathrm{~cm}$ wide, ligulate-oblanceolate, acute or acuminate. Inflorescence $130 \mathrm{~cm}$ long, laxly many-flowered, branches up to $5 \mathrm{~cm}$ long, usually with $1-2$, terminal, fertile flowers and several sterile flowers below. Sterile flowers stellate, segments ca $2-3 \mathrm{~mm}$ long, linear. Fertile flowers-floral bracts $2 \mathrm{~mm}$ long, triangular-ovate, acute. Pedicellate ovary $15 \mathrm{~mm}$ long, slender. Dorsal sepal $10 \mathrm{~mm}$ long, $2.5 \mathrm{~mm}$ wide, ligulate, without prominent claw, truncate at the apex. Petals $9 \mathrm{~mm}$ long, $5.5 \mathrm{~mm}$ wide, subsessile, obliquely elliptic-subrectangular, apically rounded or truncate. Lateral sepals $10 \mathrm{~mm}$ long, $3.3 \mathrm{~mm}$ wide, claw short, linear, blade oblong-ligulate, subobtuse, oblique. Lip $10 \mathrm{~mm}$ long and wide, sessile, somewhat cordate at the base, basal part reniform in outline, lip middle lobe bilobulate, lobules obliquely elliptic-ovate, margins entire, basal callus relatively large, irregularly sculptured, glabrous, with series of additional projections towards distal margins, below calli two papillate patches. Gynostemium $8 \mathrm{~mm}$ long, ciliate in the lower part, staminodes large, margins irregularly crenulate. 
Species similar to $H$. adelaidae, but with subrectangular-ovate petals, papillate central part of the lip, several protuberances on each lip lateral lobe, glabrous callus in form of basal, subcircular pad with some protuberances in its central part and digitate projections at the apex.

Phenology: Flowering occurs in February, July and October.

Habitats: This species grows in premontane forest at the altitudes of 1,500-2,000 m.

Distribution area: It is known exclusively from Western Andean Cordillera, Colombian departments of Antioquia and Valle del Cauca (Fig. 13).

Additional specimens examined: Colombia. Antioquia, Mpio. Urrao, Road to Pabon $4 \mathrm{~km} \mathrm{~S}$ of Urrao-Betulia road. Remaining roadside trees, $1,810 \mathrm{~m}$ a.s.l., $6^{\circ} 17^{\prime} \mathrm{N}$ $76^{\circ} 11^{\prime} \mathrm{W}, 31$ Oct 1987, A. Brant \& Betancur 1541 (MO!), Valle del Cauca, Cordillera Occidental. Yotoco. Above Buga, $1,500 \mathrm{~m}$ a.s.l., $3^{\circ} 50^{\prime} \mathrm{N} 76^{\circ} 30^{\prime} \mathrm{W}, 14 \mathrm{Jul}$ 1984, A. Gentry, M. Monsalve, A. Meerow, D. Wolfe \& T. Teefs 48077 (MO!).

Notes: Species similar to $H$. adelaidae (Fig. 15), but with subrectangular-ovate petals (vs. petals elliptic), papillate central part of the lip (vs. glabrous) and callus form. In the new species, it is glabrous, irregularly sculptured, with series of additional projections towards distal margins, while in $H$. adelaidae it is microscopically hairy at the base. Moreover, in $H$. vallecaucanum, two papillate patches are present below calli-those are absent in $H$. adelaidae. Heteranthocidium vallecaucanum resembles also H. tigratum (Rchb.f. \& Warsz.) Szlach., Mytnik \& Romowicz from which it differs by the petals shape (ovateligulate in $H$. tigratum), inconspicuous lip isthmus, larger lip lateral lobes and glabrous lip callus.

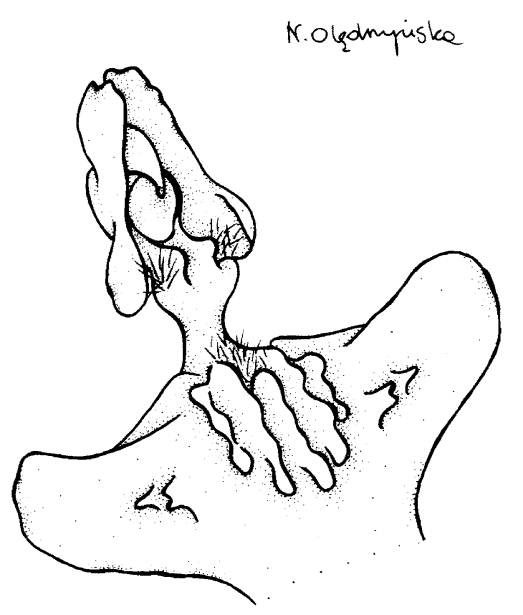

Fig. 15 Heteranthocidium adelaidae-lip details. Redrawn by $\mathrm{N}$. Olędrzyńska from Königer (1995)

\section{Taxonomic transfers}

1. Heteranthocidium ariasii (Königer) Szlach. \& Kolan., comb. nov.

三Oncidium ariasii Königer, Arcula 2: 49. 1994.-TYPE: Peru, Junin, Chanchamayo, El Sapo, 1200 m a.s.l., Nov 1985, cultivated by Arias A-497 at M, W. Königer WK-33 (holotype, M; isotypes, K, USM, Herb. Königer).

2. Heteranthocidium aspecum (Königer) Szlach. \& Kolan., comb. nov.

$\equiv$ Oncidium aspecum Königer, Arcula 5: 133. 1996.TYPE: Peru, Depto. Huanuco, between Huanuco and Tingo Maria, near the tunnel, 2700 m a.s.l., 22 Apr 1984. W. Königer, H. Königer \& M. Arias K-110c (holotype, M; isotypes, K, UNALM, USM, Herb. Königer).

3. Heteranthocidium bryocladium (Schltr.) Szlach. \& Kolan., comb. nov.

$\equiv$ Oncidium bryocladium Schltr., Repert. Spec. Nov. Regni Veg. Beih. 27: 111-112. 1924.-TYPE: Colombia, Caqueta, auf Baumen bei Mocoa, 530 m, Oct 1921, W. Hopp 157 (B-lost?).

4. Heteranthocidium cultratum (Lindl.) Szlach. \& Kolan., comb. nov.

$\equiv$ Oncidium cultratum Lindl., Ann. Mag. Nat. Hist. 15: 384. 1845.-TYPE: Colombia, Popayán. K. Hartweg s.n. (lectotype designated here, $\mathrm{K}$ !).

5. Heteranthocidium dactylopterum (Rchb.f.) Szlach. \& Kolan., comb. nov.

$\equiv$ Oncidium dactylopterum Rchb.f., Gard. Chron., n.s., 3: 684. 1875.-TYPE: [Colombia] Ocaña. A. Bruchmüller s. $n .(\mathrm{W})$.

6. Heteranthocidium echinops (Königer) Szlach. \& Kolan., comb. nov.

$\equiv$ Oncidium echinops Königer, Arcula 3: 78. 1995.TYPE: Ecuador, Morona-Santiago, bei San Juan Bosco, $1700 \mathrm{~m}$ a.s.l., 2 Aug 1993, W. Königer, H. Königer, J. Portilla et al. $K-338 a$ (holotype, M; isotypes, K, QCA, Herb. Königer).

7. Heteranthocidium heterodactylum (Kraenzl.) Szlach. \& Kolan., comb. nov.

$\equiv$ Oncidium heterodactylum Kraenzl. in H.G.A.Engler (ed.), Pflanzenr., IV, 50(80): 187. 1922.-TYPE: Ecuador, Quito, W. Jameson s.n. (W or HBG).

8. Heteranthocidium hirtzii (Dodson) Szlach. \& Kolan., comb. nov. 
$\equiv$ Oncidium hirtzii Dodson, Orquideologia 20: 276. 1997.-TYPE: Ecuador, Napo, along road from Cotundo to Hollin to Loreto, 1,000 m a.s.l., Nov 1988, A. Hirtz 3940 (holotype, RPSC!).

9. Heteranthocidium ionopterum (Rchb.f.) Szlach. \& Kolan., comb. nov.

$\equiv$ Oncidium ionopterum Rchb.f., Linnaea 41: 20. 1876. = Cyrtochilum ionopterum (Rchb.f.) Kraenzl., Notizbl. Bot. Gart. Berlin-Dahlem 7: 97. 1917.—TYPE: Peru, Huancabamba, $1000 \mathrm{ft}$, B. Roezl s.n. (lectotype designated here, $\mathrm{W}$ !).

10.

Heteranthocidium lepturum (Rchb.f.) Szlach. \& Kolan., comb. nov.

$\equiv$ Oncidium lepturum Rchb.f., Gard. Chron., n.s., 25: 41. 1886.-TYPE: Bolivia, T. Christy s.n. (W).

11.

Heteranthocidium magnificum (Senghas) Szlach. \& Kolan., comb. nov.

$\equiv$ Oncidium magnificum Senghas, Orchideen (Senghas) 172. 1993.-TYPE: Bolivia, La Paz, above Caranavi, 1,300-1,400 m a.s.l., Bot. Garden Heidelberg, Orch-770, P. Leferenz s.n. (holotype, HEID!).

12.

Heteranthocidium millei (Schltr.) Szlach. \& Kolan., comb. nov.

$\equiv$ Oncidium millei Schltr., Repert. Spec. Nov. Regni Veg. Beih. 8: 102. 1921.-TYPE: Pichincha, 2,800 m. a.s.l. Mille 17 (B - lost?).

13.

Heteranthocidium orbatum (Kraenzl.) Szlach. \& Kolan., comb. nov.

$\equiv$ Oncidium orbatum Kraenzl. in H.G.A.Engler (ed.), Pflanzenr., IV, 50(80): 180. 1922.—TYPE: unknown.

14.

Heteranthocidium ornithocephalum (Lindl.) Szlach. \& Kolan., comb. nov.

$\equiv$ Oncidium ornithocephalum Lindl., Fol. Orchid. 6: 30. 1855.-TYPE: New Grenada, Ocaña, near Sa. Maria. L. Schlim 269 (K).

15.

Heteranthocidium retusum (Lindl.) Szlach. \& Kolan., comb. nov.

$\equiv$ Oncidium retusum Lindl., Edwards's Bot. Reg. 23: sub t. 1920. 1837.-TYPE: Peru, A. Mathews s.n. (K).
16.

Heteranthocidium rostrans (Rchb.f.) Szlach. \& Kolan., comb. nov.

$\equiv$ Oncidium rostrans Rchb.f., Gard. Chron., n.s., 3: 748. 1875.-TYPE: Since loc. J. Carder s.n. (W).

17.

Heteranthocidium silvanoi (Königer) Szlach. \& Kolan., comb. nov.

$\equiv$ Oncidium silvanoi Königer, Arcula 11: 285. 2001.TYPE: Peru, Ayacucho, Prov. Huanta, Jano, 1,800 m a.s.l., W. Königer WK-108 (holotype, M; isotypes, USM, UNALM, herb. H. Königer).

18.

Heteranthocidium semele (Linden ex Rchb.f.) Szlach. \& Kolan., comb. nov.

$\equiv$ Oncidium semele Linden ex Rchb.f., Gard. Chron. 1870: 39. 1870.-TYPE: Ecuador, G. Wallis s.n. (W).

Acknowledgments The curators and staff of the cited herbaria are thanked for their kind hospitality and assistance during visits. We are grateful to Natalia Olędrzyńska for preparing line drawings and to the anonymous Reviewers for valuable suggestions on the manuscript. The project has been supported by the Polish Ministry of Science and Higher Education (Research Grant No. 5819/B/PO1/2010/39).

Open Access This article is distributed under the terms of the Creative Commons Attribution License which permits any use, distribution, and reproduction in any medium, provided the original author(s) and the source are credited.

\section{References}

Campacci MA (2006) Proposta de restabelecimento do genero Coppensia Dumort. Bol CAOB 62:54-58

Christenson EA (2006) Brevilongium, un nouveau genre neotropical (Oncidiinae). Richardiana 6(1):45-49

Dalström S (2010) Cyrtochilum Kunth. In: Dodson CH, Luer CA (eds) Flora of Ecuador 225(3): Orchidaceae; genera Cyrtochiloides-Epibator. Department of Plant and Environmental Sciences, University of Gothenburg, Sweden, pp 18-198

Docha-Neto A, Baptista DH, Campacci MA (2006) Novos generos baseados em Oncidium. Colet Orquídeas Brasil 3:65-96

Garay LA, Stacy JE (1974) Synopsis of the genus Oncidium. Bradea $1: 393-428$

Kolanowska M, Szlachetko DL (2014) Notes on Erycina-complex with descriptions of new Colombian species. Pl Syst Evol 300:527-534. doi:10.1007/s00606-013-0901-z

Kolanowska M, Perez-Escobar OA, Parra Sánchez E, Szlachetko DL (2011) An illustrated field guide to the Orchids of the Yotoco Forest Reserve (Colombia). Fundacja Rozwoju Uniwersytetu Gdańskiego, Gdańsk

Königer W (1995) New species of the genera Cyrtochilum, Masdevallia, Oncidium and Sigmatostalix. Arcula 3:58-89

Kraenzlin F (1922) Orchidaceae-Monandrae, Tribus OncidiinaeOdontoglosseae Pars II. A.Engler, Das Pflanzenreich, vol IV, 50. Engelmann, Leipzig 
Lindley J (1842) Oncidium longifolium (Cebolletae). Bot Reg 28:4-5 Lindley J (1855) Folia Orchidacea. Oncidium 37. J. Matthews, London

Lindley J, Paxton J (1850) Purple-Lipped Oncid, Oncidium haematochilum; Gleanings and original memoranda: Calanthe silvatica Lindley, Angraecum virens Lindley, Oncidium serratum Lindley, Stanhopea cirrhata Lindley, Stanhopea ecornuta E. Lemaire, Stanhopea tricornis Lindley, Acineta chrysantha Lindley, Warrea candida. Paxton's Fl Gard 1:17-32

Neubig KM, Whitten WM, Williams NH, Blanco MA, Endara L, Burleigh JG, Silveira K, Cushman JC, Chase MW (2012) Generic recircumscriptions of Oncidiinae (Orchidaceae: Cymbidieae) based on maximum likelihood analysis of combined
DNA datasets. Bot J Linn Soc 168:117-146. doi:10.1111/j.10958339.2011.01194.x

Romowicz A, Szlachetko DL (2006) Genera et species Orchidalium 12. Oncidieae. Polish Bot J 51:43-47

Senghas K (1997) Oncidiinae. Rudolf Schlecter's Die Orchideen, band I/c, 33-36. Paul Parey, Berlin

Szlachetko DL, Mytnik-Ejsmont J (2009) Gynostemia Orchidalium IV. Acta Bot Fenn 180:1-313

Szlachetko DL, Mytnik-Ejsmont J, Romowicz A (2006) Genera et species Orchidalium 14. Oncidieae. Polish Bot J 51:53-55

Thiers B (2014) Index Herbariorum: a global directory of public herbaria and associated staff. New York Botanical Garden's Virtual Herbarium. http://sweetgum.nybg.org/ih/ 